\title{
A cortical attractor network with dynamic synapses
}

\author{
Pradeep Krishnamurthy ${ }^{1 *}$, Gilad Silberberg ${ }^{2}$, Anders Lansner ${ }^{1,3}$ \\ From Twentieth Annual Computational Neuroscience Meeting: CNS*2011 \\ Stockholm, Sweden. 23-28 July 2011
}

Neocortical inhibitory interneurons play a critical role in shaping the network activity patterns by directly controlling the firing rates of pyramidal cells (PC) [1]. Evidences are accumulating for the possible role of Martinotti cells (MC), which are dendrite-targeting interneurons that receive strongly facilitating synapses from PC, as opposed to basket cells (BC) that are soma targeting and receive strongly depressing synapses [2]. We have previously developed a network model of neo- cortical layers $2 / 3$ [3] and we here extend this set-up to explore the possible division of labour between basket and Martinotti cells. We used single-compartment cells taken from Pospischill et al. [4] and implemented in NEURON [5]. Short-term depression and facilitation were incorporated for all glutamatergic and GABAergic synapses according to the formalism of Tsodyks \& Markram [6] with parameters tuned from traces provided by Silberberg et al. [2]. We commenced with

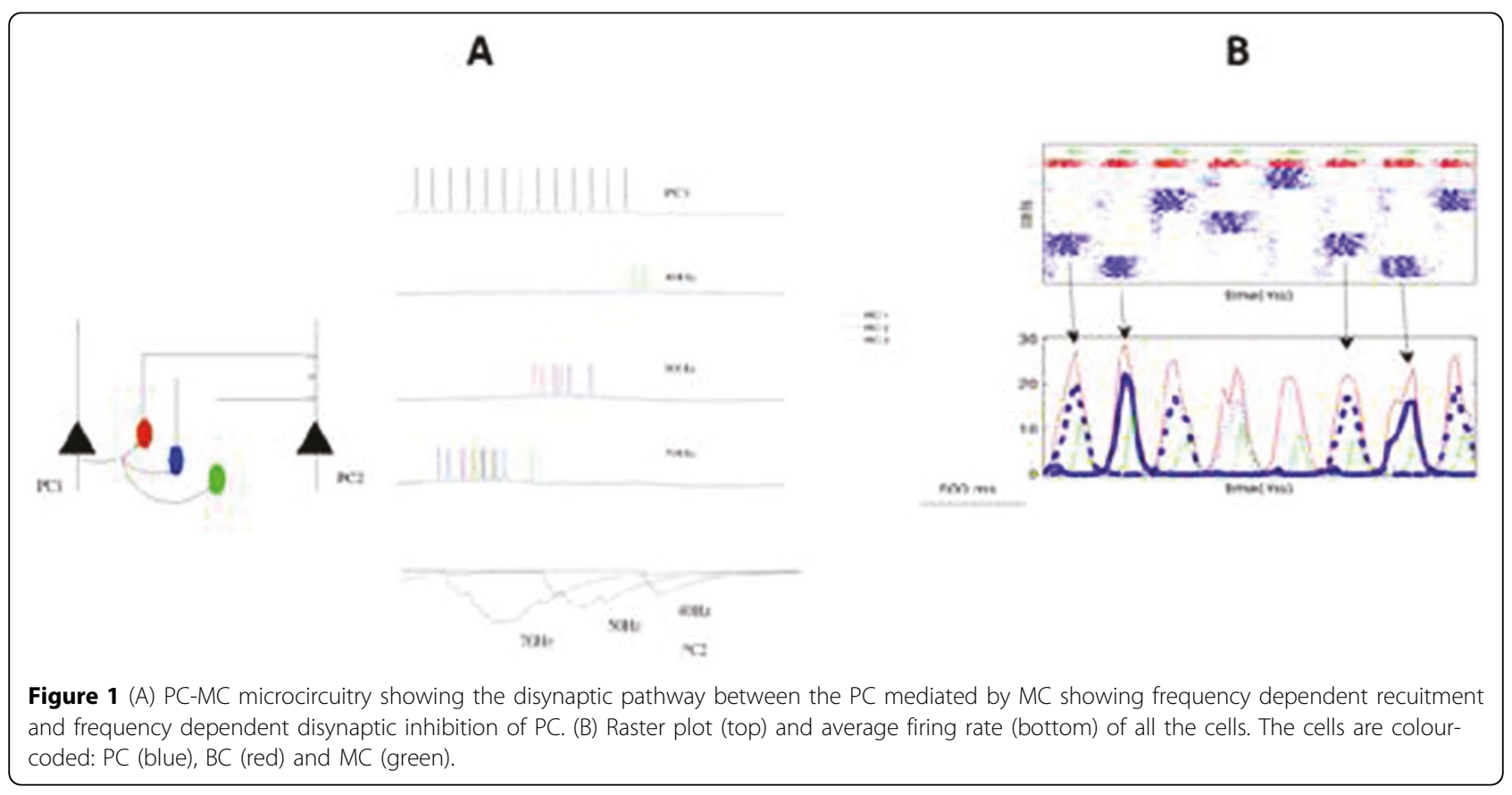

\footnotetext{
* Correspondence: pkri@csc.kth.se

'Department of Numerical analysis and Computer Science, Stockholm

University, 11421 Stockholm, Sweden

Full list of author information is available at the end of the article
}

\section{() Biomed Central}

(C) 2011 Krishnamurthy et al; licensee BioMed Central Ltd. This is an open access article distributed under the terms of the Creative Commons Attribution License (http://creativecommons.org/licenses/by/2.0), which permits unrestricted use, distribution, and reproduction in any medium, provided the original work is properly cited. 
reproducing in our model the $\mathrm{PC}-\mathrm{MC}$ microcircuit, as previously described by Silberberg \& Markram [2], and reproduced (a) frequency dependent disynaptic inhibition of $\mathrm{PC}$ and (b) frequency dependent recruitment of $\mathrm{MC}$ (Figure 1A). Thereafter, we integrated this microcircuit into our cortical network model to study the effects of $\mathrm{MC}$ on the attractor dwell time while the network is spontaneously hopping between the attractor states (stored memories) in the absence of external input. Raster plot and average firing rate (Figure $1 \mathrm{~B}$ ) show that $\mathrm{BC}$ that receive depressing synapses has a high firing rate at the beginning of the attractor state which then tapers off. On the other hand, MC that receive facilitating synapses display a late onset of activation and tend to terminate an ongoing attractor state. Cortex is provided with many mechanisms, e.g. spike frequency adaptation, synaptic depression of PC-PC synapses and late firing $\mathrm{MC}$, to control its activity levels and termination of attractors. However, our simulations show that $\mathrm{MC}$ inhibition could be a dominating factor, the high divergence of MC to PC connections also assists this.

\section{Author details}

${ }^{1}$ Department of Numerical analysis and Computer Science, Stockholm University, 11421 Stockholm, Sweden. ${ }^{2}$ Nobel Institute of Neurophysiology, Department of Neuroscience, Karolinska Institute, Stockholm, Sweden. ${ }^{3}$ Department of Computational Biology, Royal Institute of Technology (KTH), 11421 Stockholm, Sweden.

Published: 18 July 2011

\section{References}

1. Petilla 2008 Convention. [http://www.columbia.edu/cu/biologfaculty/yuste/ petilla/petilla-webpages/Nomenclature/PetillaNomenclaturefinal.pdf].

2. Silberberg G, Markram H: Disynaptic inhibition between neocortical pyramidal cells mediated by Martinotti cells. Neuron 2007, 53:735-746.

3. Lundqvist M, Rehn M, Djurfeldt M, Lansner A: Attractor dynamics in a modular network of neocortex. Network: Computation in Neural Systems 2006, 17(3):253-276.

4. Pospischill M, Toledo-Rodriguez M, Monier C, Piwkowska Z, Bal T: Minimal Hodgkin-Huxley type models for different classes of cortical and thalamic neurons. Biol Cybern 2008, 99:427-441.

5. The Neuron simulation environment. [ftp://ftp.neuron.yale.edu/neuron/ papers/nsimenv.ps].

6. Tsodyks M, Pawelzik K, Markram H: Neural networks with dynamics synapses. Neural Comput 1998, 10:821-835.

doi:10.1186/1471-2202-12-S1-P187

Cite this article as: Krishnamurthy et al:: A cortical attractor network with dynamic synapses. BMC Neuroscience 2011 12(Suppl 1):P187.

\section{Submit your next manuscript to BioMed Central} and take full advantage of:

- Convenient online submission

- Thorough peer review

- No space constraints or color figure charges

- Immediate publication on acceptance

- Inclusion in PubMed, CAS, Scopus and Google Scholar

- Research which is freely available for redistribution

Submit your manuscript at www.biomedcentral.com/submit
C Biomed Central 